\title{
COASTAL REGIONAL SEDIMENT MANAGEMENT PLAN
}

\begin{abstract}
Ronald M. Noble ${ }^{1}$ and Jon T. Moore ${ }^{2}$
Regional Sediment Management (RSM) is a planning approach that seeks to address coastal sediment processes on a broader geographic scale. It recognizes that sand, cobble, and fine sediment are important natural resources that are critical to the environmental health and economic vitality of the coastal zone. The relevant sediment processes overlap multiple geopolitical boundaries which explains why a regional planning perspective is needed. To be effective a comprehensive road map is needed to addresses how to conserve and restore the valuable sediment resources, reduce shoreline erosion and coastal storm damages, protect sensitive environmental resources, increase natural sediment supply to the coast, preserve and enhance beaches, improve water quality along the shoreline, and optimize the beneficial use of material dredged from ports, harbors, and other opportunistic sediment sources. The plan that was prepared for the diverse 144-mile long Santa Barbara and Ventura Counties coastline was developed systematically using traditional planning processes to understand the baseline science and relevant physical processes; identify the challenges that currently exist and the corresponding opportunities that can be seized to positively move forward; and formulate appropriate action plans and solutions that have unanimity of purpose. It is demonstrated that in order to be technically, environmentally, economically, and politically effective regional sediment management plans should consist of a suite of diverse study, management, policy, and capital project activities.
\end{abstract}

Keywords: regional sediment management, sediment sources and supply, coastal planning

\section{INTRODUCTION}

Regional Sediment Management (RSM) is a planning approach that seeks to address coastal sediment processes and issues on a broader geographic scale. It recognizes that sand, cobble, and fine sediment is an important natural resource that is critical to the environmental health and economic vitality of the coastal zone. The sediment is what makes up the beaches, resides offshore in significant deposits, and is delivered to the coast from inland source areas by the various rivers and streams. The relevant sediment processes extend from inland watersheds to offshore areas. This broad coverage overlaps multiple geopolitical boundaries which explains why a regional planning perspective is needed.

In order to develop a meaningful and relevant plan one must have a greater understanding and knowledge about all of the interrelationships between coastal and offshore sediment deposits, inland origins of coastal sediment, sediment pathways to the coast, and how sand moves about the shoreline. From this knowledge base, improved sediment management decisions, policies, and practices can be formulated and implemented on a regional scale to preserve or enhance existing beaches, address inter-related resource needs and opportunities, and optimally manage coastal projects for the regional benefit. It is critical that the end product be technically sound and practical, environmentally sensitive, politically realistic; and financially feasible and sustainable.

The Beach Erosion Authority for Clean Oceans and Nourishment (BEACON) is a Joint Powers Authority composed of Santa Barbara and Ventura Counties and the six cities of Goleta, Santa Barbara, Carpinteria, Ventura, Oxnard, and Port Hueneme (see Figure 1). BEACON's intent was to develop a comprehensive road map to addresses how to conserve and restore the valuable sediment resources along its coastline to reduce shoreline erosion and coastal storm damages, protect sensitive environmental resources, increase natural sediment supply to the coast, preserve and enhance beaches, improve water quality along the shoreline, and optimize the beneficial use of material dredged from ports, harbors, and other opportunistic sediment sources.

In order to formulate a specific Plan, a clear understanding of what needs to be solved and what objectives are possible should be clarified. Thus the traditional first step in any planning process is to: 1) understand the baseline science and relevant physical processes; 2) identify the challenges that currently exist and the corresponding opportunities that can be seized to positively move forward; and 3) formulate appropriate action plans and solutions that have unanimity of purpose. When applied to coastal sediment management, this planning process will allow BEACON to identify and understand its sediment

\footnotetext{
${ }^{1}$ Noble Consultants, Inc., 359 Bel Marin Keys Blvd., Suite 9, Novato, CA, 94949 USA

${ }^{2}$ Noble Consultants, Inc., 2201 Dupont Dr., Suite 620, Irvine CA, 92612 USA
} 
management goals and objectives more clearly so that strategy, policy, and capital improvement projects can be more effectively targeted and better focused to clear purpose and consensus within the coastal zone.

\section{THE BEACON COAST}

The BEACON coast includes the entire shoreline of Santa Barbara County and most of the Ventura County shoreline. The unit defines the limits of the approximately 144-mile long Santa Barbara Littoral Cell which extends from the mouth of the Santa Maria River to the Mugu Submarine Canyon. This twocounty shoreline segment may be divided into three distinct regions that vary in their shoreline orientation, physical characteristics, land use, and population density.

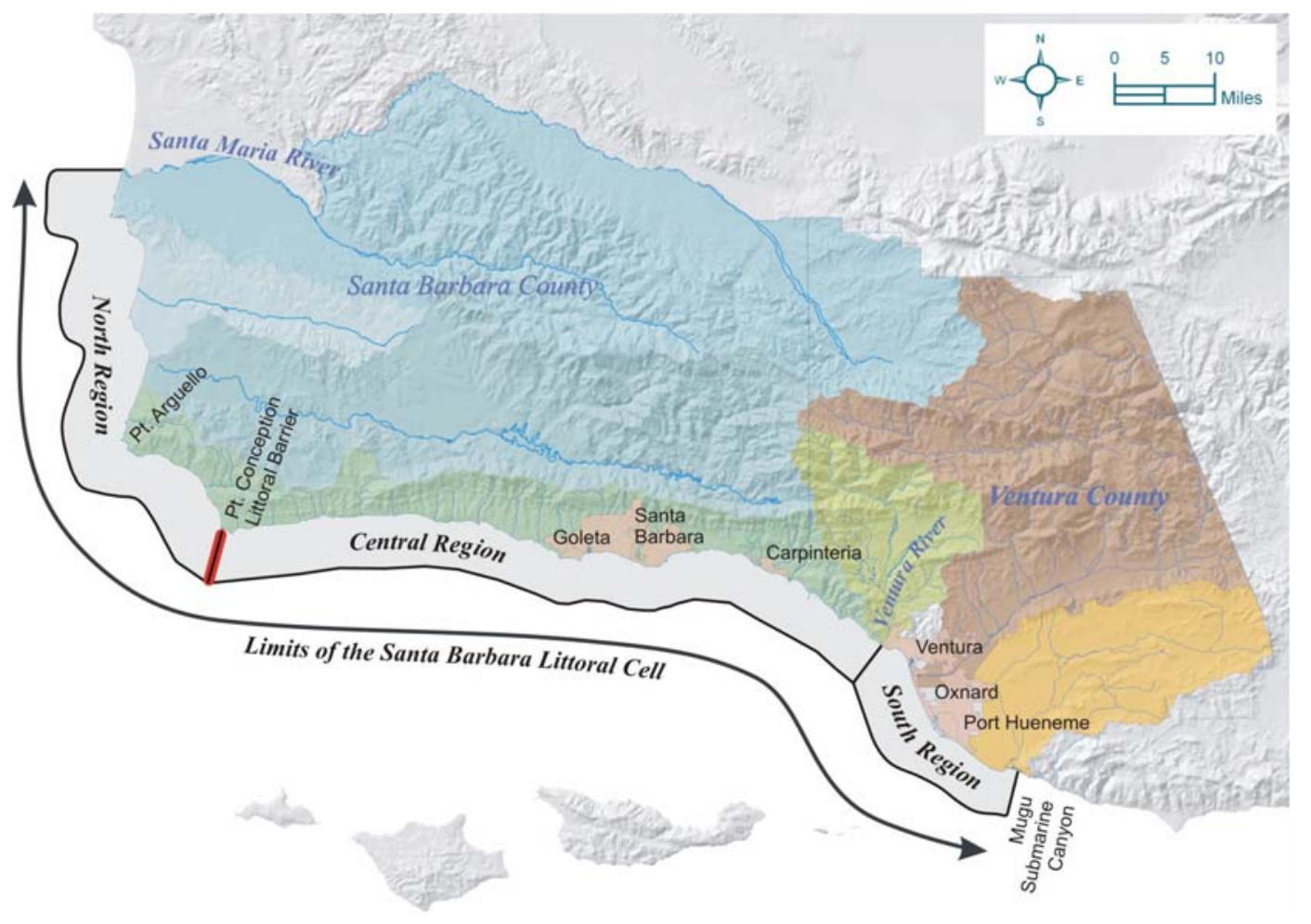

Figure 1. The BEACON Coast

The North Region is generally oriented in the north-south direction and is fully exposed to the Eastern Pacific Ocean and the northwest swell that dominates the wave climate. Isolated from the rest of the littoral cell by the natural Point Conception barrier, the prevailing scientific understanding believes that little if any sediment is able to pass around it and propagate into the Santa Barbara Channel's beaches. Because the region is relatively inaccessible and sparsely populated, sediment processes of the North Region are relatively unaltered from their natural state. Human interventions have mainly been limited to dam construction within the Santa Maria River and Santa Ynez River watersheds.

The central region of the BEACON coast is a 74-mile long stretch of shoreline that runs in a general east-west direction. Unlike the North Region, the beaches are semi-protected from Pacific Ocean swell by the Santa Barbara Channel. The shoreline is characterized as mountainous coast with narrow to nonexistent beaches that are flanked by numerous headlands and rocky points. The beaches that do exist consist of relatively thin veneers of sand over hard bedrock and are backed by high bluffs and marine terraces. Some wider sandy beaches do exist at lower relief coastal areas and stream discharge locations. The natural supply of sediment to the coast within the southern Santa Barbara County and western Ventura County region is principally from the numerous steep gradient mountain creeks that populate the Santa Ynez Mountains watershed. To a lesser extent additional sediment is contributed to the littoral system from intermittent episodes of bluff erosion particularly along the west half of the region. 
East of the Ventura River the BEACON coast opens into the broad expanse of the sediment abundant 22 mile long Oxnard Plain. The shoreline orientation has a more north to south alignment except at the east end where the beaches are more south facing. This stretch of coast is adjacent to some of the most densely populated areas within the entire littoral cell. The less developed sections that do exist are backed by wind swept dunes or wetlands. The shoreline characteristics and natural supply of sediment within this region is defined by the Ventura and Santa Clara Rivers that drain large watersheds. The Mugu Submarine Canyon is the ultimate sediment sink for the littoral cell because it provides a pathway for sand to the deep Santa Barbara Basin.

The distinct coastal regions south and east of Point Conception define the practical limits and focus of the BEACON sediment management plan. The more inaccessible shoreline north of Point Conception exists mostly in its natural state, and no sand is delivered to beaches within the Santa Barbara Channel. This means that sediment management planning for the North Region can be independent from the Central and South Region. The natural state of the North Region and existing land uses suggest that natural processes and conditions should continue to be maintained as much as possible. By contrast shoreline processes and development within the Central and South Regions are more complex. Accordingly it is this section of BEACON's urbanized coast where coastal sediment management planning focused.

\section{Central and South Region Planning Reaches}

The Central and South Region were further partitioned into smaller and more distinct reaches of shoreline in terms of differences in physical features, land use, sediment sources, and alongshore sand movement between Point Conception and the Mugu Submarine Canyon. The six reaches are shown in Figure 2 and a brief description of their distinguishing characteristics is summarized in Table 1.

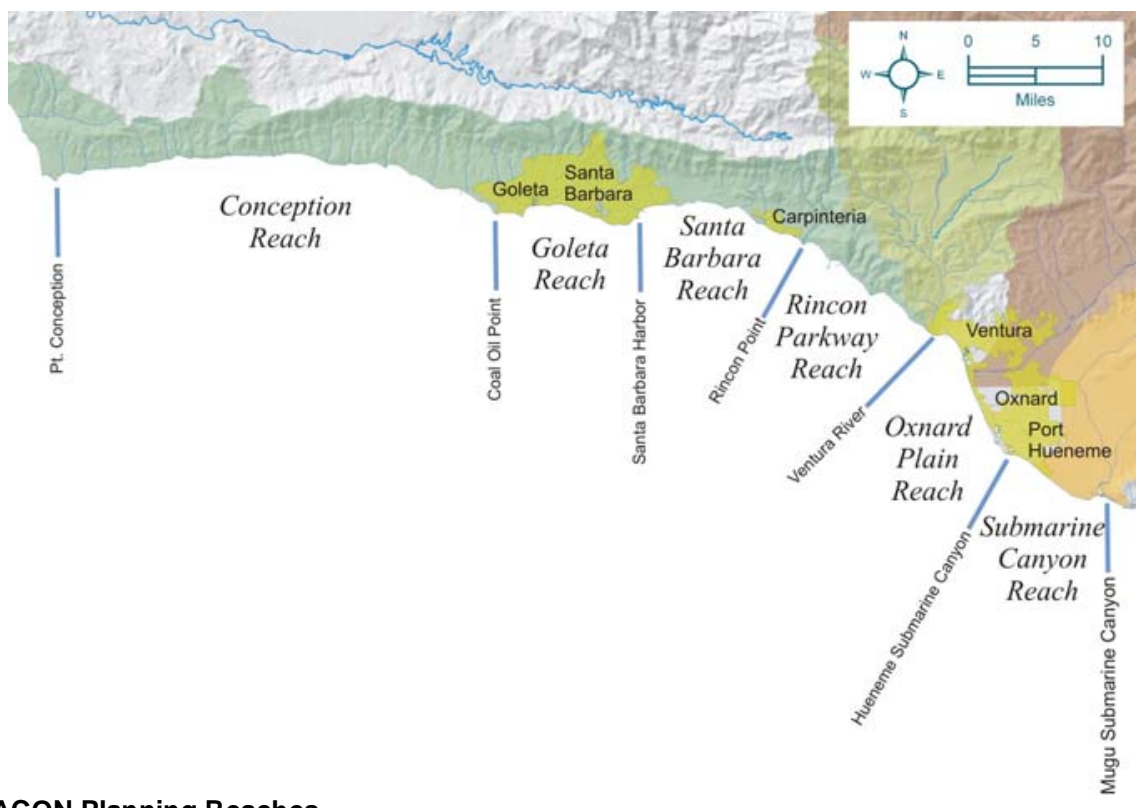

Figure 2. BEACON Planning Reaches 
Table 1. BEACON Central and South Region Planning Reaches

Planning Reach Conception

Goleta

Santa Barbara

Rincon Parkway

Oxnard Plain

Submarine Canyon
Description

A 36 mile long stretch of coast from Point Conception to Coal Oil Point near Goleta. Longest stretch of relatively undeveloped shoreline in the Santa Barbara Channel. Numerous narrow pocket beaches bounded by rocky points or headlands. The Union Pacific Railroad right-of-way is a dominate presence along much of the reach and built seawalls since the early 1900 s at seacliff toes to protect sections of tracks laid near the bluff top. Wider sandy shorelines at Ellwood may be storage beaches that serve important feeder function to nourish downcoast beaches.

Lies between Goleta and the Santa Barbara Harbor. With few exceptions beaches are narrow, backed by high bluffs, and consist of relatively thin lenses of sand over bedrock. The broad marine terrace areas that extend to the base of the Santa Ynez Mountains are densely populated. Terminus is the man-made littoral barrier at Santa Barbara Harbor, built in the late 1920s, that restricts the natural alongshore movement of sand to beaches further east.

Extends from Santa Barbara Harbor to Rincon Point. Densely populated coastline varies between areas of low lying topography and high coastal bluff areas. Orientation transitions from an eastwest alignment to a more southeasterly orientation. Beaches generally narrow pockets of sand flanked by rocky points. Some wider areas exist. Immediately northwest of Rincon Point marks the end of the wider marine terrace topography; beach there may also be another important sand storage and feeder point.

Located between Rincon Point and the Ventura River Delta. Railroad and highway development that started in the late 1800s has now armored almost the entire length with seawalls or revetments to protect development and infrastructure. Human interventions and past highway encroachments has resulted in narrow to non-existent beaches and significant alteration to the natural shoreline processes. The last segment of mountainous coast.

Located between the Ventura River and Port Hueneme Harbor. Opens into a broad and low lying alluvial plain dominated by the Ventura and Santa Clara Rivers, three man-made harbors, one submarine canyon. Mostly long and wide sandy coast historically backed by dunes. Significantly altered by development since the late 1800 s and mid 1900s. The densely populated shoreline is dependant upon continued sand bypassing at Ventura Harbor to maintain natural sediment processes and conditions. Channel Islands Harbor, located near the end of the reach, has helped to maintain wide beaches along Hollywood Beach. However the harbor was originally built in 1970 partly out of the need to remedy the littoral barrier created by the 1940 construction of Port Hueneme Harbor at the head of the Hueneme Submarine Canyon. Regular sand bypassing at Channel Islands Harbor is necessary to maintain beaches downcoast.

Extends from Hueneme Submarine Canyon (Port Hueneme Harbor) to the Mugu Submarine Canyon. The western end is fully developed, but opens into wider stretches of undeveloped wetlands, dune fields, and inaccessible low density military base land to the southeast. Long sandy beaches backed by the low lying topography of the alluvial plain. The beaches are completely dependant upon regular sand bypassing from Channel Islands Harbor since the 1940 construction of Port Hueneme Harbor. The Mugu Submarine Canyon is the terminus of the reach and the entire Santa Barbara Littoral Cell. The canyon ultimately captures all sand from the upcoast.

\section{UNDERSTANDING the BEACON COAST}

Since the 1940s a number of coastal studies and research have been performed to develop an understanding of the basic coastal processes, wave climate, and shoreline evolution that describe how the Santa Barbara and Ventura County coastline behaves. Additional data and information has become available more recently through technical studies, field data collection programs, and coastal projects. Studies conducted or underway include the Corps of Engineers' Coast of California Storm and Tidal Waves Study, the USGS California Urban Ocean Project, and graduate research conducted at the UC Santa Cruz Institute of Marine Science and elsewhere. Additional data and information has also been produced from the results of more focused studies and projects such as BEACON's South Central Coast Beach Enhancement Program (SCCBEP) development, the Goleta Beach Demonstration Project, and local agency projects such as Ventura's Surfers Point Project and the County of Santa Barbara's Goleta Beach Master Plan study and project. In particular, the USGS and Santa Cruz studies have proposed some new interpretations of coastal processes within BEACON's shoreline. This insight together with past research is available to help guide the overall sediment management planning process and summarize a current 
understanding of the BEACON coast. From this understanding of how the shoreline behaves appropriate sediment management plans and strategy can be considered.

Development along the coast and the need to protect property and infrastructure has significantly altered portions of the Central and South Regions. Numerous seawalls and revetments have been built to protect railroad and highway infrastructure particularly within the Conception and Rincon Parkway Reaches. The Conception Reach remains as the least armored area east of Point Conception. Knowledge about the beach processes and long term shoreline trends east of Point Conception varies with the level of study that has been conducted thus far. In general the net response of the shoreline will depend upon the occurrence and intensity of storm exposure, the width of existing beaches, the volume and frequency of sediment discharged to the coast by rivers and streams during rainfall episodes, and the extent of man's intervention and interruption to the various natural processes. A brief summary of this understanding and the data gaps of knowledge is provided in Figure 3.
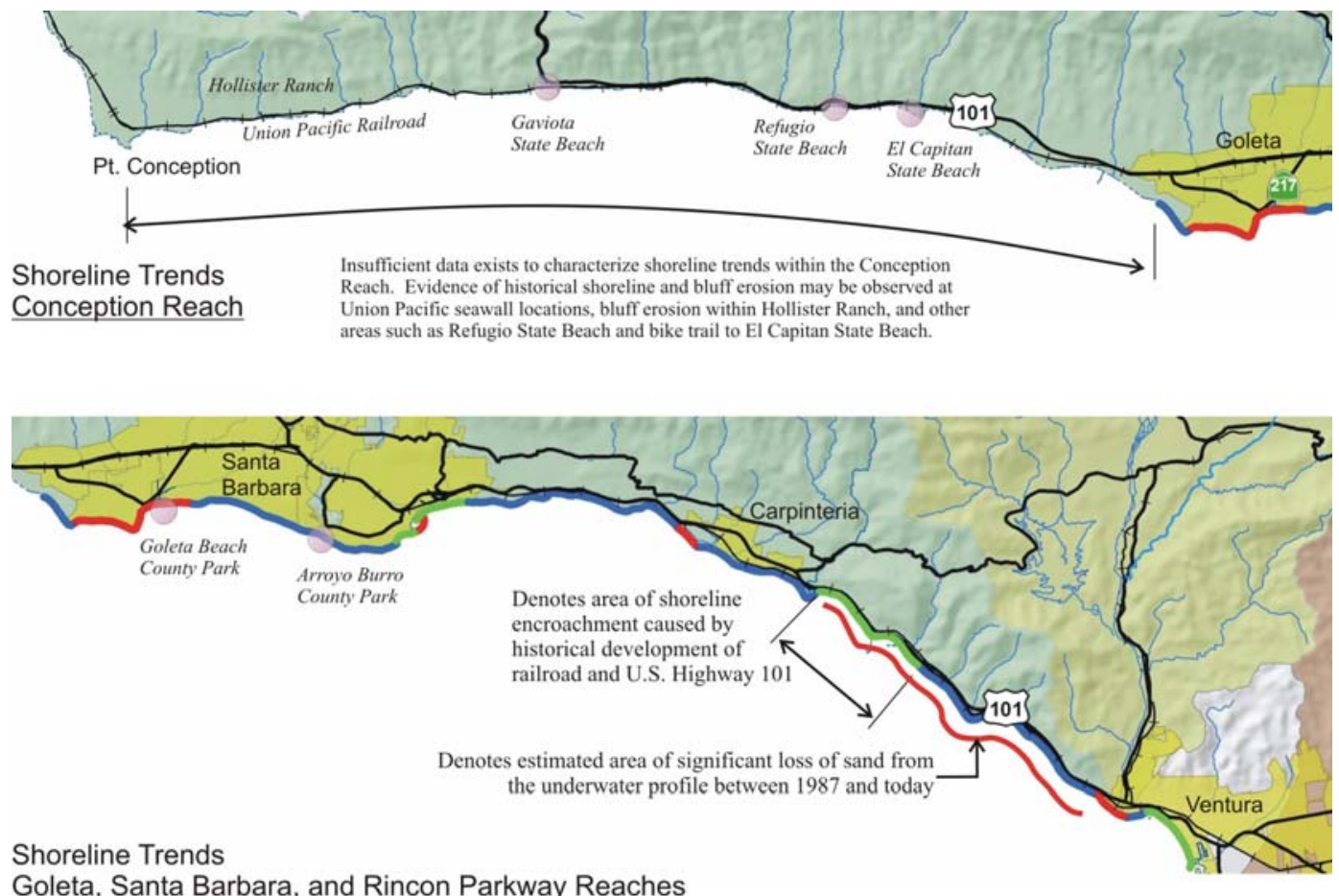

Goleta, Santa Barbara, and Rincon Parkway Reaches
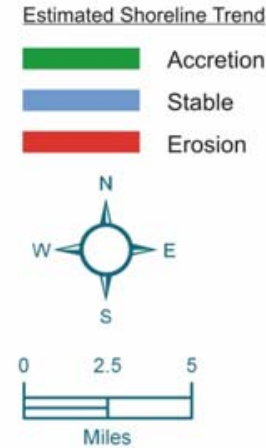

Shoreline Trends Oxnard Plain and Submarine Canyon Reach

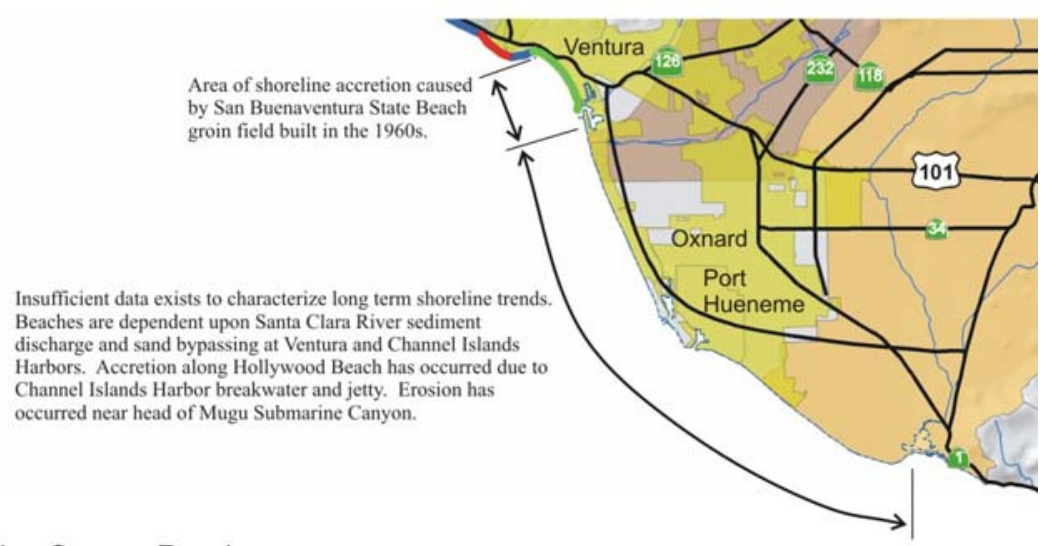

Insufficient data exists to characterize long term shoreline
Beaches are dependent upon Santa Clara River sediment Beaches are dependent upon Santa Clara River sediment
discharge and sand bypassing at Ventura and Channel Island Harbors. Accretion along Hollywood Beach has occurred due to Channel Islands Harbor breakwater and jetty. Erosion has occurred near head of Mugu Submarine Canyon.

Figure 3. Shoreline Trends between Point Conception and the Mugu Submarine Canyon 


\section{Littoral Sediments}

The beaches within the BEACON Coast are naturally nourished by the tributary rivers and streams that discharge mainly from seven watersheds (see Figure 4). The volume of sand and fine grained sediment that is delivered to the shoreline will vary from year to year in response to the amount of rainfall and runoff that occurs. East of Point Conception, littoral sediment supply is dominated by the Santa Ynez Mountains watershed and the Ventura and Santa Clara Rivers. Alteration of the natural watershed to address flood protection or water storage needs has an impact to the shoreline in terms of reduced sediment supply to the coast. Over time the cumulative impacts of human interventions may result in diminishing beach widths or other impacts. Although dam construction has significantly reduced the delivery of sand to the BEACON Coast (see Table 2), Warrick and Farnsworth (2007) has shown that the mean annual fine sediment contributions (silt and clay sized material) from rivers and streams can be at least as much as the corresponding sand delivery values or substantially higher.

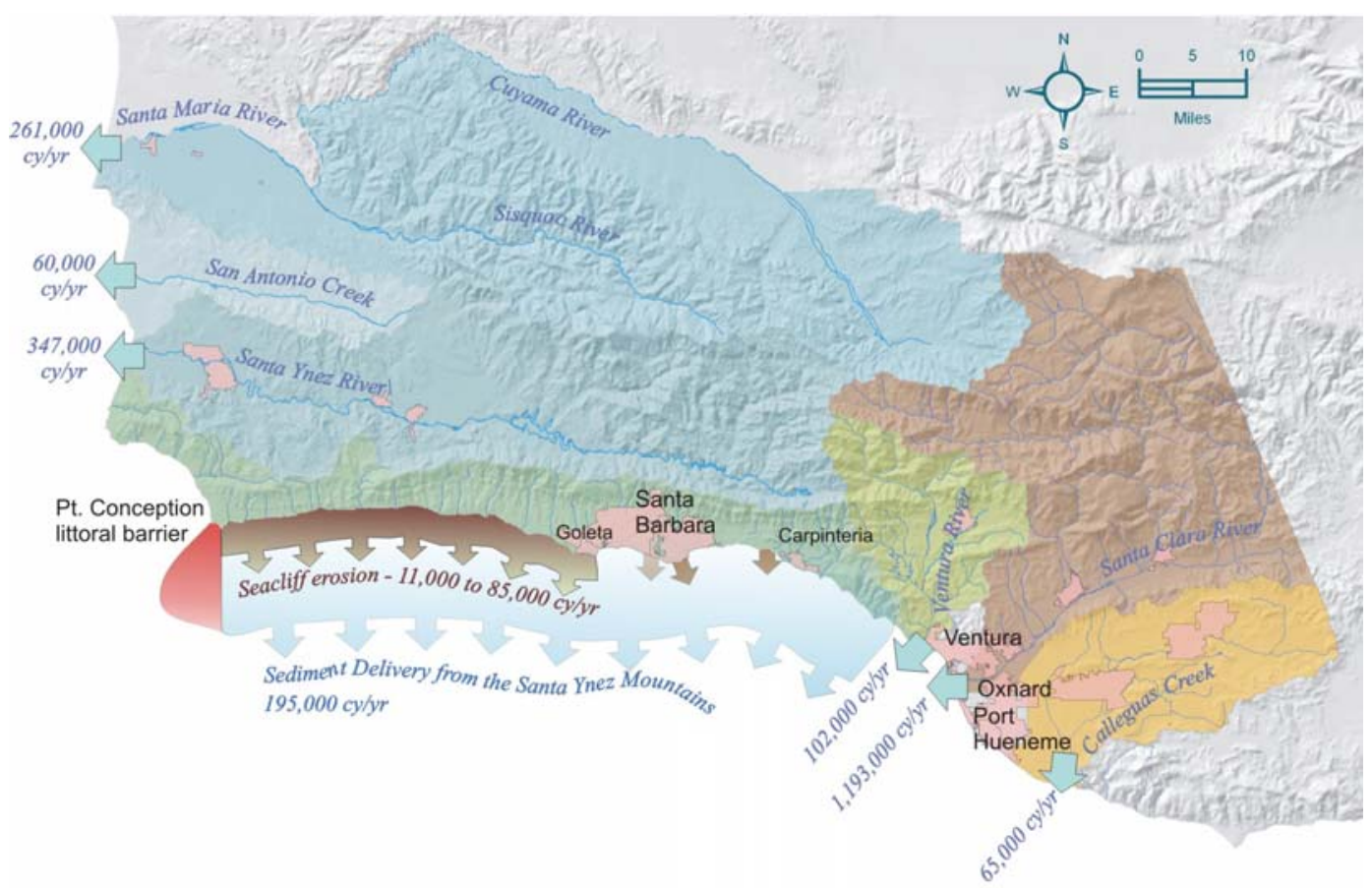

Figure 4. Fluvial and Seacliff Sediment Sources along the BEACON Coast

Table 2. Estimated Sediment Supply to the Coast from Rivers and Streams

Watershed

Santa Maria River

San Antonio Creek

Santa Ynez River

Santa Ynez Mountains Watershed

Ventura River

Santa Clara River

Calleguas Creek

$\begin{array}{ccc}\text { Fluvial Delivery Volume (cy/yr) } & \text { Reduction (\%) } \\ \text { Pre-dam } & \text { Post-dam } & 68 \\ 811,000 & 261,000 & 0 \\ 60,000 & \text { (No dams) } & 51 \\ 713,000 & 347,000 & 0 \\ 195,000 & \text { (No dams) } & 53 \\ 216,000 & 102,000 & 27 \\ 1,634,000 & 1,193,000 & 0 \\ 65,000 & \text { (No dams) } & \end{array}$

Source: Willis and Griggs, 2003

The episodic erosion of seacliffs that occurs primarily between Point Conception and Santa Barbara is the other significant source of sediment that is naturally delivered to the shoreline. Estimates of the quantity of sand that enters the littoral system over time vary between scientific studies. Runyan and Griggs (2003) have proposed that only sediment with grain sizes greater than 0.125 millimeters in diameter meaningfully contribute to nourishment of sandy beaches. Using this sediment size cutoff criteria the natural contribution from bluff erosion between Point Conception and Santa Barbara would be about 14,000 cubic yards per year under all natural conditions. Considering the effects of seacliff armoring and erosion protection which 
has reduced erosion by an estimated twenty percent, the present-day contribution may also be reduced to a volume on the order of 11,000 cubic yards per year. However this volume constitutes only about 3.6 percent of the average annual maintenance dredging volume at Santa Barbara Harbor (315,000 cubic yards per year).

Other scientists differ on that amount of sand that seacliffs may contribute to the coast. Diener (2000) considers littoral sediments as fine sand ( $>0.0625$ millimeters) in his research. Using his criteria and study results, the contribution of sand from seacliff erosion may be much larger or about 106,000 cubic yards per year. After accounting for seacliff armoring effects, a net contribution volume of about 86,000 cubic yards per year is estimated. This value represents over one-forth of the sand that is dredged on average from Santa Barbara Harbor.

\section{Other Available Sand Sources}

In addition to the natural supply of sediments, additional sources exist within the BEACON Coast that may be considered to supplement the natural processes. Sources include debris basin sediment, trapped sediment behind dams, estuarine deposits, and offshore sand sources. Finding ways and means to allow the impounded sand upstream remains a daunting challenge. Offshore sand sources exist at four known locations and potentially other yet to be explored regions within the nearshore coastal shelf. These deposits, totaling in the millions of cubic yards and constitute the most significant resource of sand that is available for beach renourishment and supplementation of littoral sediment budgets.

\section{Sediment Budget}

The BEACON Coast is the Santa Barbara Littoral Cell. As previously discussed this geological unit extends from the Santa Maria River mouth to the Mugu Submarine Canyon where the cell ends. North of Point Conception, alongshore transport travels predominantly from north to south in response to the prevailing northwest sea and swell from the Pacific Ocean. However the mountainous coast between Point Arguello and Point Conception blocks most if not all sand from rounding the point and entering the Santa Barbara Channel. Thus it is still believed that the two regions north and east of Point Conception are isolated from one another.

East of Point Conception the shoreline orientation and partial shelter afforded by the offshore Channel Islands results in a net alongshore sand transport from west to east. As schematically depicted in Figure 5 this unidirectional sediment current means that all sand between Point Conception and Port Hueneme ultimately propagates toward the Mugu Submarine Canyon where it is forever lost to the system.

The state of knowledge about how the sediment is delivered to the coast and how it moves alongshore is improving and evolving with continued monitoring and scientific study of the shoreline processes. However significant unknowns and data gaps still exist. More is understood between the populated coast of Goleta to Port Hueneme. Less has been studied within the Conception and Submarine Canyon Reaches.

The understanding of alongshore sand movement has been deduced mainly from study of the sand that accumulates at Santa Barbara, Ventura, and Channel Islands Harbors. Each harbor is a littoral sand trap, and regular maintenance dredging is required to maintain sand supply to the downcoast beaches. The annual average volume of sand that is dredged from each harbor indicates the increasing gradient of sand movement along the BEACON Coast from west to east:

- Santa Barbara Harbor - 315,000 cubic yards per year.

- Ventura Harbor - 597,000 cubic yards per years

- Channel Islands Harbor - 1,010,000 cubic yard per year.

Port Hueneme Harbor requires little dredging since most of the sand is trapped immediately upcoast at Channel Islands Harbor and the harbor entrance is located at the head of the Hueneme Submarine Canyon. 


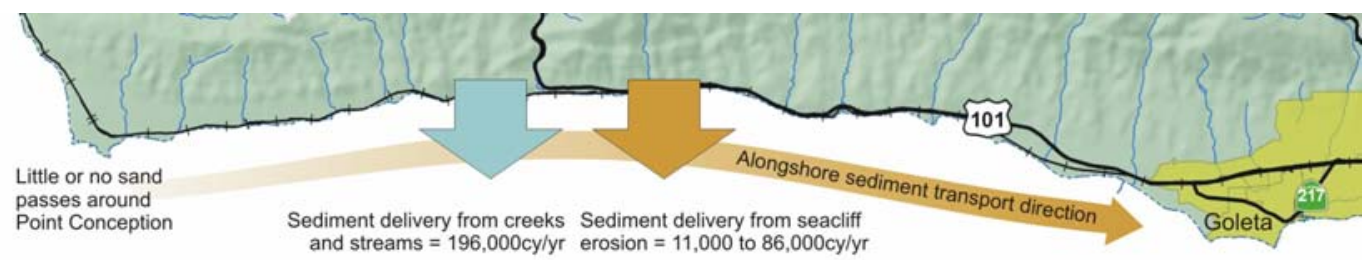

Conception Reach
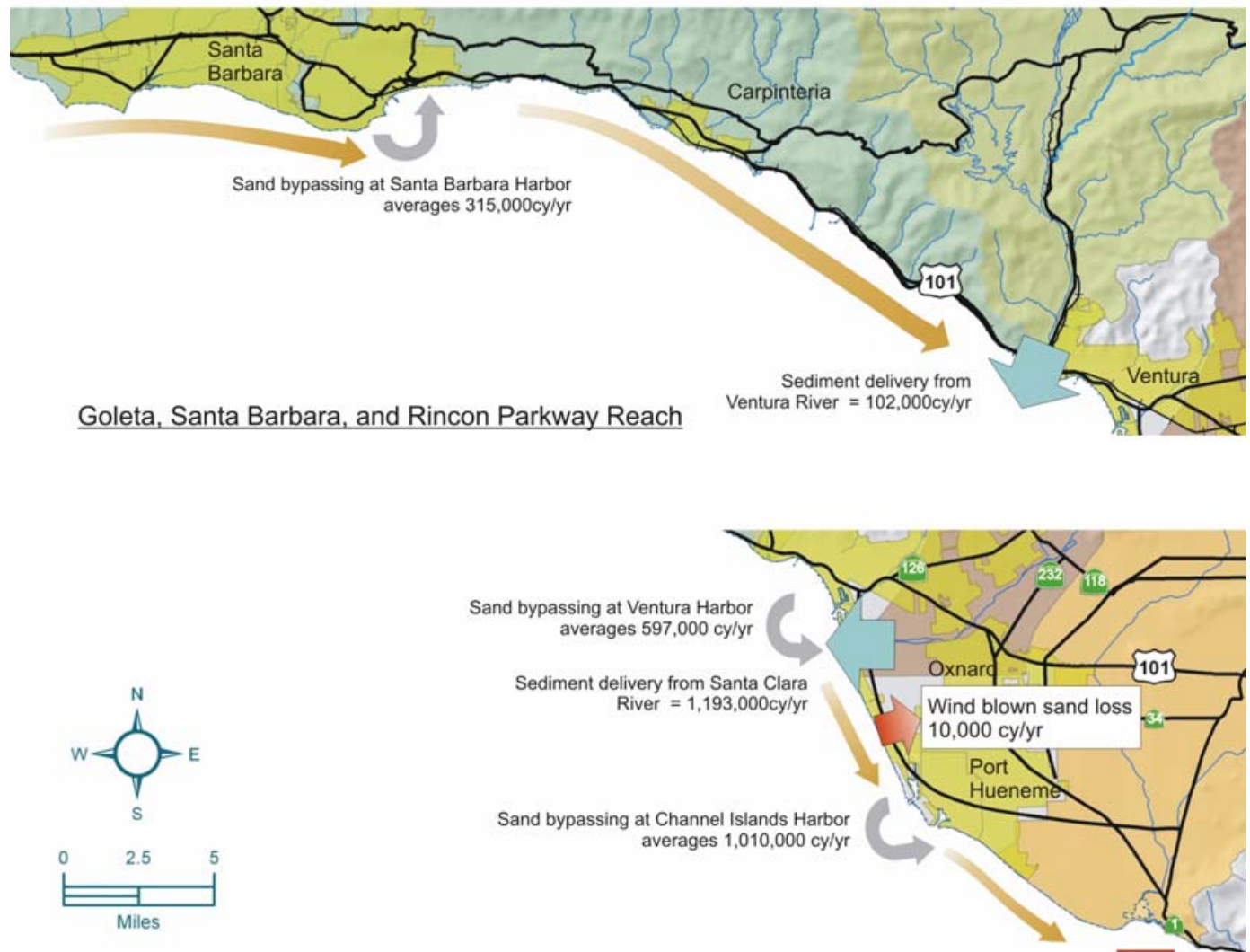

Sediment delivery from Santa Clara ver $=1,193,000 \mathrm{cy} / \mathrm{yr}$

Oxnard Plain and Submarine Canyon Reach

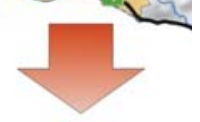

All sand lost to the Mugu Submarine Canyon

Figure 5. Schematic Diagram of Shoreline Processes along the BEACON Coast

The South Region is considered to be sediment abundant which means there is always sand on the beach that can be moved regardless of the duration and intensity of the incident waves. In contrast the beaches within the western portion of the Central Region are considered to be sediment limited. Therefore the amount of wave energy that impacts the shoreline is capable of moving more sand than exists on the beach. Under these conditions the relatively thin deposits of sand that form the narrow sediment limited beaches can be quickly stripped away as the sand transport capability of the incident waves (potential sand transport) exceeds the smaller volume of sand that is present and moved (actual sand transport). Once the sand is removed and the beach is depleted of sand, the sand transport rate is substantially reduced as there is no more sand available to be moved. Thus the potential rate of alongshore sediment transport rate may be higher than the actual sand transport that occurs along the beaches of the Central Region. This theory has significant implications for artificial sand placements on beaches in the sediment limited Central Region as the added sand could quickly diminish unless measures are taken to prolong its longevity. 
Sediment delivery along the BEACON Coast varies over time in response to the frequency and amount of rainfall that occurs from year to year. Similarly the movement of sand along the coast also varies over time depending upon the changes in ocean wave climate over time and the intensity of winter storms that impact the coast. A reasonable understanding of the average shoreline processes is known, but more monitoring, research, and study is needed to better understand the variability of sand delivery and movement along the coast and how different reaches respond to each change.

\section{CHALLENGES and OPPORTUNITES}

From a general perspective, the BEACON shoreline is one that has been significantly altered since the early 1900's as a consequence of the population and development growth that accelerated during the middle portion of the $20^{\text {th }}$ century. The ensuing development encroachment, infrastructure protection, disruption to watersheds, and other human interventions that occurred over this period impacted much of the Santa Barbara and Ventura Counties shoreline and its natural processes. By necessity certain man-made solutions were needed to restore and maintain the imbalances that resulted. However, specific actions have spawned conflict between advocates of shoreline retreat and abandonment to reverse adverse conditions versus those who prefer to integrate urbanization with environmentally sensitive planning and solutions. Within the coastal zone, political compromises often do not satisfy the technical and scientific requirements for an adequate and complete solution.

Sediment management issues span a diverse group of agencies and stakeholders that are directly or indirectly impacted by attempts to balance natural processes with the multiple competing needs and interests. For example, harbors may be reluctant to relinquish control over their sediment sources, and watershed districts may rank upland priorities above the needs of the shoreline. In the absence of collaboration, finding areas of common ground to beneficially reuse sediment or preserve the natural supply of sand to the coast will be difficult. Presently there are conflicting priorities on how the available sediment resources within the region should be used. Offshore sand resources contain finite amounts of beach compatible material. Taking sand from some of the known areas may raise concerns about permanent loss to habitats. Decisions will need to be made concerning the types of habitats that are impacted and if the resource in question is sufficiently abundant or can be enhanced elsewhere so that careful offshore mining of sand can proceed.

Clearly beach preservation within some areas of the BEACON shoreline will depend upon the ability to find appropriate ways to retain and preserve existing beaches. Traditional practices of sand retention solutions will not be politically appropriate on the BEACON Coast. However, it is becoming more apparent that without some means to increase the longevity of sand on the beach, opportunities to preserve, restore, or enhance beaches will become less feasible particularly in Santa Barbara County.

Sediment management is currently constrained by funding limitations. The cost of meaningful projects can often exceed the ability of local agencies to implement unless there is substantial state and federal funding participation.

Lastly, the sediment management permit process is onerous. Specific project proposals or strategies must comply with special conditions that are daunting and costly. The myriad of permit requirements, overlapping and inconsistent authorities, and approvals that must be obtained can discourage participation in the most basic of sediment management activities such as sand of opportunity contributions. On a larger scale resource agencies have an inherent discomfort with beach nourishment projects unless all aspects of the project description are detailed to a level of certainty that may exceed the engineers' and scientists' current predictive state-of-the art abilities.

The problems that currently face sediment management along the BEACON shoreline can be elevated by restating these challenges as opportunities. In this manner a specific challenge transcends from its negative context to a positive statement from which effective solutions can be proposed, considered, and implemented. The specific challenges that face the BEACON coast may be categorized into four general areas that are related to either: coastal processes and sand sources, upland watersheds, development, and governance. Based upon the current understanding of the Santa Barbara and Ventura Counties shoreline the challenges and opportunities summarized in Table $\mathbf{3}$ exist for resolution by the sediment management plan. 
Table 3. Challenges and Opportunities for the BEACON Coast

Challenge

Opportunity

\section{Coastal Processes and Sand Sources:}

1. Offshore sediment sources are mostly finer than the native beaches.

2. Most if not all of the littoral sand within the Santa Barbara Littoral Cell is permanently lost to the Region's submarine canyons.

3. Beaches are inadequate to provide storm damage protection.

4. Current projections for sea level rise indicate that shoreline recession rates may accelerate.

5. Wind blown sand along the Pierpont and Oxnard Shores area creates a nuisance and in some cases property damage.

6. Sand of opportunity is difficult to anticipate and capture.

Watershed Systems:

7. Sediment delivery from rivers and streams is reduced significantly by watershed alteration.

8. Sediment delivery from rivers and streams fluctuates significantly over time due to climatic variation.

Development:

9. Long stretches of the Santa Barbara and Ventura County shoreline are armored.

10. Maintenance of existing harbors is inconsisten and driven by Federal budget constraints.

11. Development and infrastructure within the coastal zone can adversely impact sediment supply and shoreline processes.

\section{Governance:}

12. Securing regulatory entitlements for sediment management projects is onerous, expensive, and discourages participation.

13. Beach nourishment projects usually require a cost share component.

14. A single local agency cannot by itself initiate regional sediment management policies and projects.

\section{THE REGIONAL SEDIMENT MANGEMENT PLAN}

As previously discussed the six planning reaches within the BEACON Central and South Region are distinguished from one another by their unique differences in shoreline characteristics and land uses. The different physical settings, micro-climates and wave exposures within these reaches have influenced in part where communities have developed and recreational opportunities exist. The diversity of the BEACON shoreline suggests that its regional sediment management plan should consist of a suite of equally diverse strategy, policy, and capital projects to effectively respond to the following specific sediment management challenges and needs of the area: beach preservation and maintenance, beneficial reuse of sand trapped at harbors, preservation of natural sources of sediment delivery, beneficial retrieval of offshore and inland sand sources to supplement existing coastal sediment resources, implementation of innovative and 
alternative technology to maximize the longevity of sand on the beach, and funding needs. Each of these challenges and needs are discussed further below.

\section{Beach Preservation and Maintenance}

The Santa Barbara County coastline is generally characterized as being sediment limited and more vulnerable to differences in sediment supply to the coast and the natural transport processes associated with waves and currents. These conditions imply that portions of the Central Region would benefit from sand nourishments that are implemented appropriately to maintain the existing sandy beach or enhance areas that are currently experiencing sediment deficiencies and need of sand. Conversely the low lying sand abundant shoreline within the South Region has naturally longer and wider beaches. The greater volumes of sand that are periodically delivered to the South Region by the Ventura and Santa Clara Rivers define the health and condition of the region. This relative sediment abundance of the shoreline between the Ventura River and the Mugu Submarine Canyon suggests that beach preservation strategies are more appropriate to maintain the existing abundant conditions.

\section{Beneficial Reuse of Harbor Trapped Sand}

The four harbors within the BEACON Coast extend from Santa Barbara to Port Hueneme. Given the potential impact each harbor can have on the natural system it is important to preserve the existing practice of sand bypassing and maximize opportunities whereby the trapped sediments may be placed on the nearby beaches to derive the maximum benefit.

\section{Natural Sediment Sources}

The most significant source of natural sediment supply to the BEACON Coast is that delivered by the numerous creeks, streams, and rivers that discharge within the different regions. The Ventura River and Santa Clara River are the most dominant sources, but the sediment budget is also critically dependant upon the lesser known and smaller streams that drain the southern face of the Santa Ynez Mountains watershed within the Conception Reach. Seacliff sediments provide an important contribution along the Central Region. Preservation of the major natural sources of sediment to the coast should remain a priority.

\section{Supplemental Sand Sources}

Ways and means to appropriately inject additional sources of sand into the littoral system should remain a high priority. Continued exploration and confirmation of offshore sand reserves will provide BEACON with the resources to address long term deficiencies in sediment supply on a larger scale. Capture of beach compatible sediments from inland sources that otherwise might not find their way to the shoreline will be beneficial to the beaches.

Innovative Technology to Maximize Sand Longevity on the Beach

The BEACON Coast is unique in that the alongshore sediment transport along its shoreline is predominantly unidirectional. This characteristic coupled with the more sediment limited beaches of Santa Barbara County places additional constraints upon the feasibility of beach preservation and nourishment projects. Sand that is placed upon the beach without some form of retention strategy will be short lived. Therefore preservation of existing beaches and enhancement efforts will only be effective when combined with appropriate ways to retain sand.

Traditional coastal structures such as groins and breakwaters have been used effectively to stabilize beaches in the past, however their use in the future is unlikely to be favored. The challenge then is to find an effective sand retention methodology that is environmentally consistent with the BEACON Coast. In response to this challenge the BEACON Regional Sediment Management Plan should seek ways to demonstrate and implement new and innovative sand retention technologies that are more compatible with the Santa Barbara and Ventura Counties shoreline setting and provide multi-purpose benefits of beach preservation, biological enhancement, and increased recreation opportunities. The demonstration project at Oil Piers that is being tested in collaboration with the U.S. Army Corps of Engineers presents a promising submerged reef methodology that if successful can lead to new opportunities for innovative beach restoration, preservation, and enhancement. 


\section{Funding Needs}

The economic realties associated with coastal sediment management and projects implementation dictates that funding sources and revenue streams be in place to pay for the expensive capital costs that are inherent in the program. Collaboration with state and federal agencies will remain in the foreseeable future as the most viable means to fund sediment management and beach preservation and enhancement programs. This partnership will continue to require local cost sharing in order to move forward. Therefore the scope of BEACON's Plan will depend upon the ability to develop and maintain the minimal funding streams necessary to produce the required state and federal matching fund percentages.

\section{The Recommended Plan}

The above general concepts have been formulated into a suite of recommended studies, management strategy, policy, and capital projects. Collectively they represent the specific recommended activities for the BEACON CRSMP. A graphical summary of the Plan is shown in Figures 6a and $6 \mathbf{b}$.

The Plan includes a number of regional and reach specific activities. Those that are common to the entire BEACON Coast such as strategy and governance issues are best addressed from the regional perspective. Commensurate with the diversity of the BEACON Coast is a list of specific activities on a reach by reach basis. These recommended studies, management practices, policies, or capital projects proposals are geographically divided into the unique stretch of coastline where they apply.

The BEACON Sediment Management Plan represents a long term plan for coastal sediment management within the BEACON Coast. The Plan is meant to be implemented over the next twenty years although clearly its various components may be selectively implemented in proportion to the level of available staffing and funding available to carry out and complete the various activities. Recognizing that resources may be limited priorities may be established to focus initiative and efforts to those tasks that are more critical or offer more immediate regional or reach benefit. 


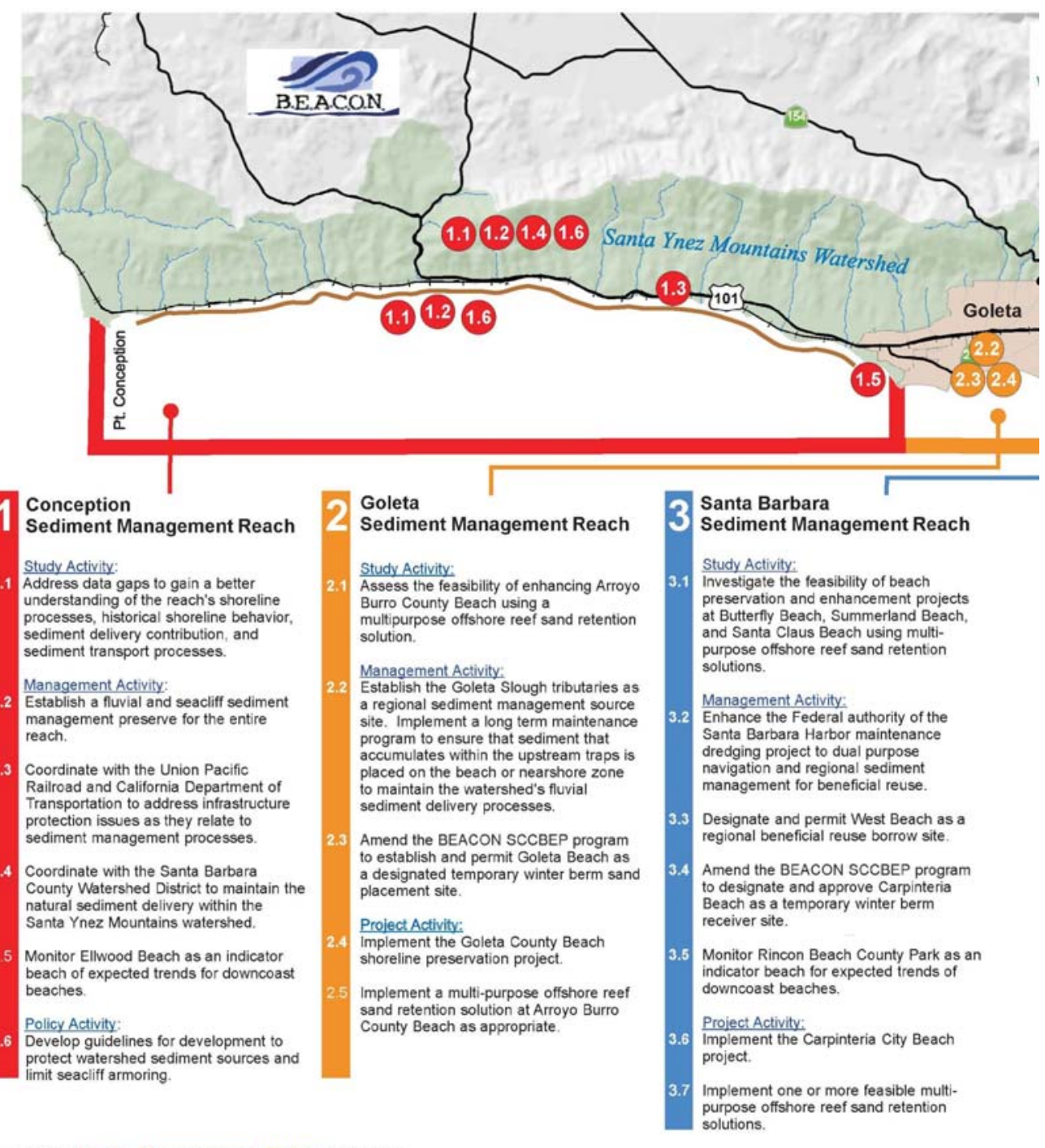

Region Wide Study, Management, Policy Activities

R1 Characterize offshore sand sources.
R2 Evaluate innovative and alternative multi-purpose sand
retention solutions.

Coordinate with USGS and UCSB to establish long term monitoring of shoreline and sediment processes.

Amend BEACON SCCBEP permits to support smaller scale programs.

Conduct frequent staff interaction with federal and state funding agencies including watershed related agencies.

Figure 6a. The Recommended BEACON Regional Sediment Management Plan 


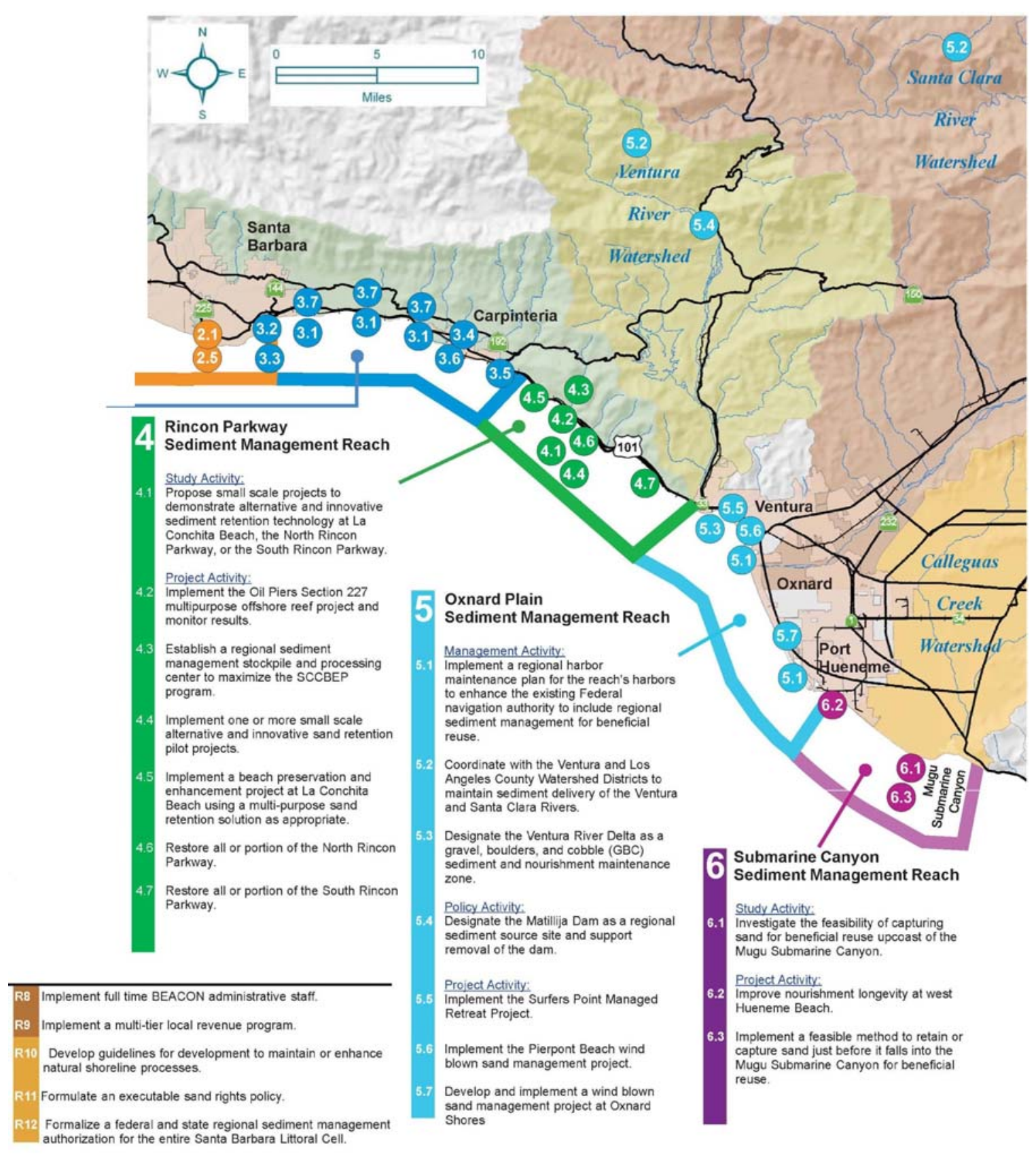

Figure 6b. The Recommended BEACON Regional Sediment Management Plan (continued from Figure 6a 


\section{REFERENCES}

Barnard, P.L. et al. 2009, Coastal processes study of Santa Barbara and Ventura Counties, California, USGS Open File Report 2009-1029.

Diener, B.G. 2000. Sand Contribution From Bluff Recession Between Point Conception And Santa Barbara, CA. Shore and Beach 68(2)7-14.

Noble Consultants. 2009. Coastal regional sediment management plan, central coast from Pt. Conception to Pt. Mugu. Prepared for Beach Erosion Authority for Control Operations and Nourishment, Santa Barbara, CA.

Noble Consultants. 1989. Coastal sand management plan, Santa Barbara / Ventura County Coastline. Prepared for Beach Erosion Authority for Control Operations and Nourishment, Santa Barbara, CA.

Revell, D. L. and Griggs, G.B. 2007. Regional shoreline and beach changes in the Santa Barbara sandshed. Coastal Sediments '07, Proceedings of the $6^{\text {th }}$ International Symposium on Coastal Engineering and Science of Coastal Sediment Processes, ASCE, New Orleans, LA, Volume 3.

Runyan, K.B., and Griggs, G.B. 2003. The effects of armoring seacliffs on the natural sand supply to the Beaches of California. Journal of Coastal Research 19(2) 336-347.

Warrick, J.A. and Farnsworth, K.L. 2007. Sources of sediment to the coastal waters of the Southern California Bight, Chapter 2.2 - Sources of sediment to the coastal waters of the Southern California Bight. Earth Science in the Urban Ocean: The Southern California Continental Borderland. Geological Society of America, Special Paper Number 454, pp. 39-52

Willis, C.W. and Griggs, G.B. 2003. Reductions in fluvial sediment discharge by coastal dams in California and implications for beach sustainability. Journal of Geology 111:167-182. 